\title{
Implementasi Capacitated Vehicle Routing Problem with Time Windows dengan Pendekatan Algoritma Sweep untuk Distribusi Pengangkutan Sampah
}

\author{
Dedi Sa'dudin Taptajani ${ }^{1}$ \\ Jurnal Kalibrasi \\ Sekolah Tinggi Teknologi Garut \\ Jl. Mayor Syamsu No. 1 Jayaraga Garut 44151 Indonesia \\ Email : jurnal@itg.ac.id \\ 1deditaptajani@itg.ac.id
}

\begin{abstract}
Abstrak - Vehicle Routing Problem (VRP) merupakan suatu permasalahan yang berkaitan dengan bagaimana menentukan rute yang dianggap optimal dan melibatkan lebih dari satu alat angkut demi memperhatikan beberapa kendala dalam melayani sejumlah tempat layanan sesuai dengan permintaan. Salah satu varian dari VRP adalah capacitated vehicle routing problem with time window (CVRPTW) varian ini menambahkan kendala kapasitas alat angkut sebagai salah satu pertimbangan didalam mengangkut ke masing masing tujuan dan kemudian memberikan jendela waktu didalam proses pengangkutannya. Tujuan dari penulisan ini adalah menjelaskan pembentukan model dari CVRPTW untuk permasalahan rute pengangkutan sampah dari tiap rumah Sampai Ke Tempat Pembuangan Akhir, dengan pertimbangan waktu yang tersedia dan kapasitas angkut alat angkut yang tersedia, Sedangkan Penyelesaiannya yaitu dengan menggunakan pendekatan algoritma sweep. Algoritma Ini merupakan algoritma yang terdiri dari dua tahap, pada tahapan pertama yaitu clustering dari masing masing rumah dan tahap selanjurtnya yaitu membentuk rute pengiriman untuk masing-masing cluster dengan metode Nearest Neighbour, kemudian dilanjutkan dengan menentukan kapasitas alat angkut terhadap waktu yang diperlukan untuk menentukan kapan sampah ini akan di angkut ke tempat pembuangan akhir. Studi ini sangat penting dilakukan dalam rangka menerapkan dasar untuk memahami kemungkinan meningkatkan tingkat layanan pada proses pengangkutan sampah di tingkat desa.
\end{abstract}

Kata Kunci - Algoritma; Nearest Neighbour; Pengangkutan Sampah; Vehicle Routing Problem.

\section{PENDAHULUAN}

Perkembangan teknologi e-commers memaksa keadaan lingkungan harus bisa beradaptasi dengan cepat pada kebiasaan saat ini, dimana banyak orang melakukan aktifitas belanja online dengan aplikasi yang nantinya berkibat kepada menumpuknya sampah rumah tangga akibat penggunaan packaging plastic yang mengharuskan penggunaan itu untuk meminimalisir terjadinya kerusakan barang pada saat pengiriman, namun ternyata itu menimbulkan effect yang sangat buruk terhadap adanya penumpukan sampah yang terjadi di msing masing daerah. Untuk menanggulangi sampah tersebut maka perlu dilakukan proses pengangkutan sampah yang dilakukan oleh masyarakat setempat guna menjadikan lingkungan yang sehat dan bersih, dalam proses pengangkutan sampah yang dilakukan perlu adanya tahapan atau cara yang husus agar pada saat proses pengangkutan sampah bisa terorganisir dengan baik, mengingat tidak adanya petugas khusus yang dilakukan di masing masing daerah dalam proses pengangkutan sampah [1],[2].

Penggunaan media grobak berkapasitas $0,8 \mathrm{~m}^{3}$ diharapkan mampu menyisir sampah yang ada di lingkungan masyarakat secara optimal. Hanya saja proses pengangkutan sampah dilakukan secara swadaya oleh masyarakat yang berkaitan dengan penjadwalan di lingkungan. 
varian VRP dengan tambahan time windows lebih dikenal dengan Capacitated Vehicle Routing Problem with Time Windows (CVRPTW) [3]. Time windows sendiri bisa diartikan sebagai batasan dari waktu operasional pekerjaan, atau batasan waktu suatu kendaraan bisa mngirimkan sampah. Model ini diharapkan mampu menyelesaikan masalah yang terjadi saat ini, dimana penumpukan sampah di masing masing rumah tidak memperhatikan Beberapa penelitian terkait algoritma yang digunakan untuk menyelesaikan permasalahan CVRPTW [4].

Belum adanya penentuan rute perjalanan membuat sulit aparatur desa didalam melaksanakan tugas membersihkan sampah, apabila ada satu atau dua alat angkut yang harus diperbaiki maka timbunan sampah yang tidak terangkut akan makin menumpuk. Maka penentuan rute pengangkutan sampah dari rumah warga menuju TPS harus diperhatikan supaya proses pengangkutan sampah menjadi lebih optimal karena berhubungan dengan efisiensi jarak dan biaya. Oleh karena itu, efisiensi sub-sistem ini diharapkan menjadkan proses pengangkutan sampah dari Rumah menuju TPS dapat menghemat jarak, waktu dan biya pengangkutan [5]. Aparatur desa sudah memiliki rute sendiri dalam proses pengangkutan sampah tetapi tidak menggunakan metode khusus dalam penggunan rekayasa penentuan rute sehingga rute yang digunakan tidak mempertimbangkan jarak yang ditempuh, kemudian untuk setiap rute menjadi tidak seimbang karena rute pengangkutan yang digunakan masyarakat tidak memperhatikan utilitas kapasitas kendaraan, sehingga beban sampah yang diangkut masing-masing kendaraan di setiap rute tidak merata, untuk menentukan rute pengangkutan sampah serta menjadwalkan sejumlah kendaraan yang terbatas dari tiap-tiap rumah menuju TPS dengan menentukan rute yang harus dilalui berdasarkan kepada volume kapasitas alat angkut [6],[7].

Proses pengangkutan sampah di Daerah yaitu mulai dari Rumah sampai berakhir di Tepat Pembuangan Sementara (TPS) yang baik sesuai dengan apa yang kita harapkan, atau pendistribusian yang optimal merupakan langkah untuk mempercepat sampainya sampah ke tempat pembuangan akhir [8]. Sehingga pada proses pengambilan sampah ke tiap rumah, masing-masing alat angkut membawa sampah dengan kapasitas yang optimal, tanpa ada kendaraan yang kosong, ketika kendaraan sampai di Tepat Pembuangan Akhir (TPA), pentingnya proses pengambilan sampah yang optimal merupakan salah satu cara yang baik di dalam pendistribusian sampah, sehingga pada saat kendaraan mengirim sampah itu harus mempertimbangkan rute terpendek pada jalur pengangkutan sampah, sehingga diharapkan mampu mengoptimmalkan kendaraan yang ada [9],[10].

Untuk mencapai pemakaian sarana transportasi atau kendaraan yang ideal, dan pola pengangkutan yang optimal, maka diperlukan suatu model, yang dapat menggambarkan berbagai masalah dalam bidang pengangkutan, Selain itu juga, diperlukan suatu metode sebagai pemecahan masalah untuk menyelesaikan kasus tersebut [11]. Dengan permodelan tersebut, akan memudahkan pencarian solusi untuk menemukan rute paling pendek pada sejumlah kendaraan dengan biaya yang minimal, sehingga tidak ada kendaraan yang mengeluarkan biaya tinggi karena terlalu banyak mengirimkan sampah atau terlalu jauh ketika proses pengiriman sampah dilakukan [12].

\section{METODOLOGI PENELITIAN}

Untuk menentukan rute pengangkutan sampah dari masing masing rumah ke tempat pembuangan sampah sementara ini dilakukan dengan cara mengambil sampah didatangi ke ujuan atau rumah warga. masing masing menggunakan gerobak sampah yang sudah disediakan pihak desa, kemudian menentukan urutan rute pengangkutan sampah yang akan dilalui serta menentukan jumlah alat angkut berdasarkan kapasitas alat angkutyang ada ( gerobak sampah), dengan adanya skema ini diharapkan mampu memperoleh rute terpendek dari titik titik sampah yang dilalui yaitu rumah warga yang akan membuang sampah, dengan memperhatikan kapasitas sampah yang maksimal sehingga akan menghemat waktu, biaya, dan jarak, berikut alur penentuan pemecahan masalah pengangkutan sampah dengan pendekatan metode alghoritma sweep sebagai alternatif penentuan rute dan meminimukan jarak atau waktu dan alat angkut dengan pertimbangan kendala-kendala yang ada saat ini. 


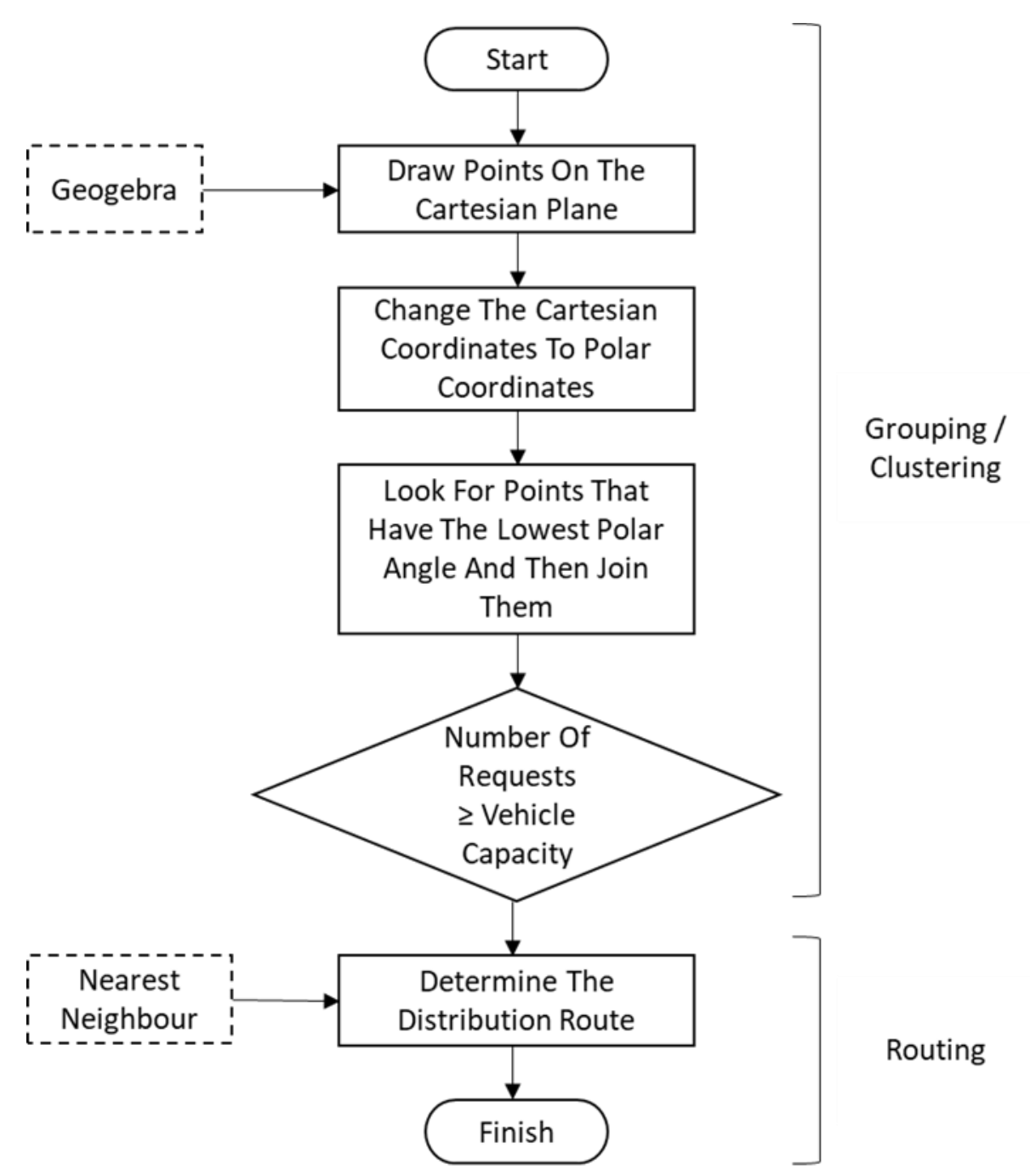

Gambar 1: Flow Chart penyelesaian pengangkutan sampah untuk kasus CVRPTW

Pada Model CVRPTW ini akan dilakukan clustering setiap Rumah Warga yang ada pada wilayah yang akan diteliti serta dilalui oleh sejumlah alat angkut yang dilakukan secara bersamaan. dengan mempertimbangkan sejumlah alat angkut yang akan melakukan pengangkutan secara bersamaan. Data-data yang dibutuhkan pada penelitian ini adalah data jalur pengiriman sampah mulai dari RUMAH WARGA ke TPS, Kapasitas Alat angkut, jumlah alat angkut dan jenis alat angkut yang dipakai untuk mengangkut Sampah. dilakukan Grouping / clustering pada setiap Rumah yang ada pada wilayah yang akan diteliti serta dilalui oleh sejumlah alat angkut yang dilakukan secara bersamaan. dengan mempertimbangkan kapasitas angkut pada masing masing kendaraaan [13],[14]. Data-data yang dibutuhkan pada penelitian ini adalah data titik titik POOL, rumah dan TPS dalam bentuk gambar atau peta sehingga nantinya akan diubah menjadi titik kordinat kartesius dengan bantuan software geogebra, selanjutnya adalah jumlah kapasitas angkut pada masing masing angkutan untuk mengetahui batasan dari proses pengelompokan. Kemudian dilakukan penentuan rute kendaraan yang akan dilalui sesuai dengan urutan yang sudah diperhitungkan dengan pendekatan Nearest Neighbour, data yang diperlukan pada tahapan routing ini adalah matrix jarak antar Rumah, jarak antara rumah ke TPS, serta rumah mana saja yang akan dilalui berdasarkan pengelompokan sebelumnya. Proses ini diharapkan mampu memberikan solusi optimal pada saat melakukan pendistribusian bahan baku kulit tersebut. pengolahan data ini untuk memecahkan permasalahan kasus dari model CVRPTW dengan menggunakan Algoritma sweep, metode ini sangat sederhana sehingga mudah untuk diimplementasikan dalam penentuan rute kendaraan. 


\section{HASIL DAN PEMBAHASAN}

Dari 612 Tempat atau rumah yang membuang sampah (RUMAH WARGA), Satu Tempat Pembangan Sementara (TPS) dengan pendekatan algoritma sweep maka dihasilkan 4 rute pengiriman sampah, kemudian terdapat 4 pool dimana ini mengacu kepada jumlah RW yang ada di Daerah, 612 rumah warga yang tiap hari membuang sampah dan 1 TPS didalam proses pengiriman sampah, dimana semuanya tersebar di beberapa titik yang ada Daerah. Proses pertama yang dilakukan sebelum menentukan rute perjalanan adalah menentukan lokasi depot pada pemetaan dengan bantuan map lalu kemudian diubah menjadi koordinat kartesius dengan bantua software geogebra yang selanjutnya akan diubah menjadi koordinat polar. Ada beberapa tahapan perhitungan sebelum kepada penentuan Rute berdasarkan pendekatan Algoritma sweep, yaitu tahapan Grouping / clustering dari setiap rumah, berikut Tabel hasil perhitungan yang dilakukan antara lain :

Tabel 1: Hasil grouping / clustering

\begin{tabular}{|c|c|c|c|c|}
\hline No & kelompok 1 & kelompok 2 & kelompok 3 & kelompok 4 \\
\hline 1 & $\mathrm{Q}$ & $\mathrm{P}$ & $\mathrm{G} 1$ & $\mathrm{D}$ \\
\hline 2 & $\mathrm{R}$ & $\mathrm{C} 1$ & $\mathrm{~L}$ & $\mathrm{~N} 1$ \\
\hline 3 & $\mathrm{I}$ & $\mathrm{N}$ & $\mathrm{W}$ & $\mathrm{O} 1$ \\
\hline 4 & $\mathrm{~S}$ & $\mathrm{M} 1$ & $\mathrm{~F} 1$ & $\mathrm{U}$ \\
\hline 5 & $\mathrm{Q} 1$ & $\mathrm{~J} 1$ & $\mathrm{E}$ & $\mathrm{P} 1$ \\
\hline 6 & $\mathrm{H}$ & $\mathrm{M}$ & $\mathrm{F} 1$ & $\mathrm{~K} 1$ \\
\hline 7 & $\mathrm{~J}$ & $\mathrm{E} 1$ & $\mathrm{D}$ & $\mathrm{L} 1$ \\
\hline 8 & $\mathrm{H} 1$ & $\mathrm{~K}$ & $\mathrm{~B} 1$ & \\
\hline 9 & $\mathrm{~T}$ & $\mathrm{O}$ & $\mathrm{V}$ & \\
\hline 10 & $\mathrm{Z}$ & $\mathrm{A} 1$ & & \\
\hline 11 & & $\mathrm{G}$ & & \\
\hline
\end{tabular}

Setelah didapatkan hasil pengelompokan berdasarkan urutan dari proses grouping dengan pertimbangan kapasitas angkut, maka perhitungan selanjutnya adalah menentukan jarak terpendek dari rumah ke TPS dan jarak masing masing Rumah, selanjutnya adalah pembentukan rute dari masing masing cluster yang telah diperoleh pada tahapan sebelumnya dan akan diselesaikan dengan menggunakan metode Nearest Neighbour sehingga dapat diperoleh urutan rute perjalanan dari masing-masing cluster, yaitu menentukan satu titik yang akan menjadi titik awal perjalanan dimana dalam penelitian ini sudah ditentukan bahwa titik awal perjalanan dimulai dari Pool / garasi alat angkut sampah (KANTOR RW) kemudian dilanjutkan ke Rumah, pilih titik Rumah yang akan dikunjungi selanjutnya yaitu Rumah terdekat dengan melihat jarak paling minimum dengan titik yang sudah terpilih sebelumnya, kemudian lakukan langkah seperti sebelumnya sampai semua titik pada cluster dikunjungi 


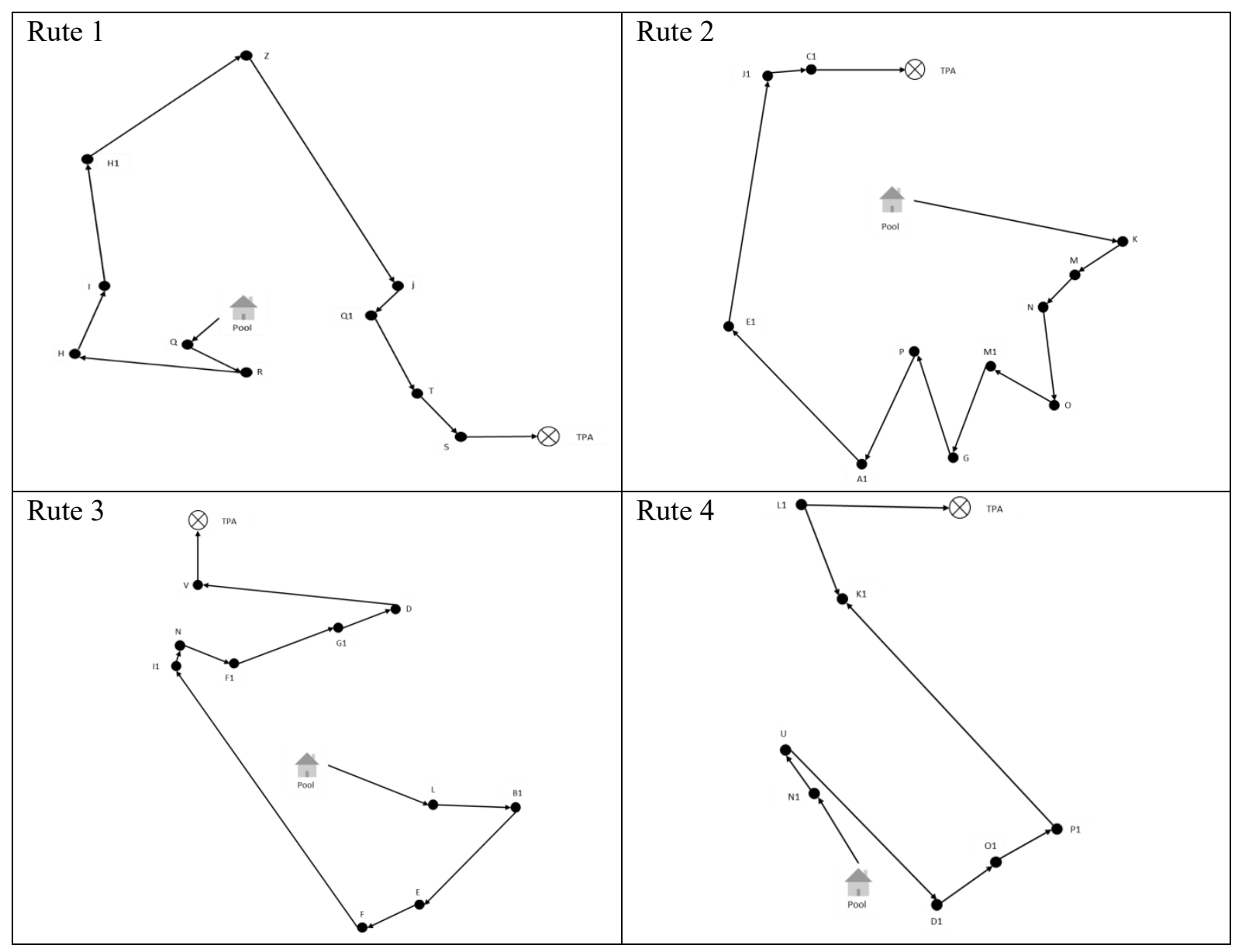

Gambar 2: Rute Pengiriman Sampah di Daerah

empat rute inilah yang diharapkan menjadi solusi optimal pada pendistribusian sampah di kota garut. Karena kita ketahui selama ini pola pendistribusian sampah di Daerah belum pernah ditentukan rute perjalanannya, dengan menggunakan pendekatan suatu metode. Adapun proses pengiriman sampah itu dilaksanakan atas dasar pengetahuan si pengantar.

\section{KESIMPULAN}

Dari hasil perhitungan total jarak pada rute 1 sebesar $\pm 2,8 \mathrm{~km}$, rute 2 sebesar $\pm 3,1 \mathrm{~km}$, rute 3 sebesar $\pm 1,1$ $\mathrm{km}$, rute sebesar $\pm 1,42 \mathrm{~km}$ dengan menggunakan 8 unit alat angkut diharapkan mampu mengoptimasi jarak dari kondisi semula yang semberawut tida memiliki pola kebijakan rute yang harus dilalui, dan sekarang setelah dilakukan penelitian diharapkan akan menjadi lebih optimal baik dari sisi jarak, waktu, dan pengangkutan.

\section{DAFTAR PUSTAKA}

[1] T. A. M. Toffolo, T. Vidal, and T. Wauters, "Heuristics for vehicle routing problems: Sequence or set optimization?," Comput. Oper. Res., 2019, doi: 10.1016/j.cor.2018.12.023.

[2] N. Gamayanti, A. Alkafi, and R. Mangatas, "Optimisasi Multi Depot Vehicle Routing Problem ( MDVRP ) dengan Variabel Travel Time Menggunakan Algoritma Particle Swarm Optimization,” JAVA J. Electr. Electron. Eng., 2015. 
[3] Lukmandono, M. Basuki, M. J. Hidayat, and F. B. Aji, “Application of Saving Matrix Methods and Cross Entropy for Capacitated Vehicle Routing Problem (CVRP) Resolving,” 2019, doi: 10.1088/1757899X/462/1/012025.

[4] F. Arnold and K. Sörensen, "Knowledge-guided local search for the vehicle routing problem," Comput. Oper. Res., 2019, doi: 10.1016/j.cor.2019.01.002.

[5] S. H. Huang and P. C. Lin, "Vehicle routing-scheduling for municipal waste collection system under the 'Keep Trash off the Ground' policy," Omega (United Kingdom), 2015, doi: 10.1016/j.omega.2015.02.004.

[6] F. Stavropoulou, P. P. Repoussis, and C. D. Tarantilis, "The Vehicle Routing Problem with Profits and consistency constraints," Eur. J. Oper. Res., 2019, doi: 10.1016/j.ejor.2018.09.046.

[7] R. Pérez-Rodríguez and A. Hernández-Aguirre, "A hybrid estimation of distribution algorithm for the vehicle routing problem with time windows," Comput. Ind. Eng., 2019, doi: 10.1016/j.cie.2019.02.017.

[8] S. T. Bae, H. S. Hwang, G. S. Cho, and M. J. Goan, "Integrated GA-VRP solver for multi-depot system," Comput. Ind. Eng., 2007, doi: 10.1016/j.cie.2007.06.014.

[9] L. Wen and R. Eglese, "Minimum cost VRP with time-dependent speed data and congestion charge," Comput. Oper. Res., 2015, doi: 10.1016/j.cor.2014.10.007.

[10] M. Casazza, A. Ceselli, and R. Wolfler Calvo, "A branch and price approach for the Split Pickup and Split Delivery VRP,” Electron. Notes Discret. Math., 2018, doi: 10.1016/j.endm.2018.07.025.

[11] V. Baradaran, A. Shafaei, and A. H. Hosseinian, "Stochastic vehicle routing problem with heterogeneous vehicles and multiple prioritized time windows: Mathematical modeling and solution approach," Comput. Ind. Eng., 2019, doi: 10.1016/j.cie.2019.03.047.

[12] Y. H. Huang, C. A. Blazquez, S. H. Huang, G. Paredes-Belmar, and G. Latorre-Nuñez, "Solving the Feeder Vehicle Routing Problem using ant colony optimization," Comput. Ind. Eng., 2019, doi: 10.1016/j.cie.2018.10.037.

[13] R. J. Kuo, B. S. Wibowo, and F. E. Zulvia, "Application of a fuzzy ant colony system to solve the dynamic vehicle routing problem with uncertain service time," Appl. Math. Model., 2016, doi: 10.1016/j.apm.2016.06.025.

[14] B. Sawik, J. Faulin, and E. Pérez-Bernabeu, "A Multicriteria Analysis for the Green VRP: A Case Discussion for the Distribution Problem of a Spanish Retailer," 2017, doi: 10.1016/j.trpro.2017.03.037. 